\title{
Framework Agreement as a Regulator of Economic Relations, Business and Financial Activities
}

\author{
Sergey Yu. Morozov ${ }^{*}$, Marina $N$. Ilyushina ${ }^{2}$, Vitaly $V$. Izmailov ${ }^{3}$, and Kama K. \\ Dzhindzholiya $^{4}$ \\ ${ }^{1}$ Ulyanovsk State University, Department of Civil and Business Law, Ulyanovsk, Russia \\ ${ }^{2}$ All-Russian State University of Justice (Russian Law Academy of the Ministry of Justice of Russia), \\ Department of Civil and Business Law, Moscow, Russia \\ ${ }^{3}$ Moscow Region State University, Department of Civil Law, Moscow, Russia \\ ${ }^{4}$ Kutafin Moscow State Law University (MSAL), Department of Business and Corporate Law, \\ Moscow, Russia
}

\begin{abstract}
Very It seems relevant to consider a framework agreement on the implementation of economic activity, business and financial activities due to two circumstances: 1) framework agreements are most widespread in the sphere of economics, since it is the persons engaged in entrepreneurial activity who most of all need long-term planning of their economic interests and the distribution of financial resources; 2) certain types of framework agreements, named in the Civil Code of the Russian Federation, are most widespread in the economy and the sphere of finance, digital technologies, that is, they are most often used in doing business. Purpose of research: the study of organizational relations developing in the field of economic activity, the definition of the problems of framework agreements both in doctrinal and legislative and law enforcement aspects in the field of economic and financial relations, as well as the development of proposals for improving legislation in this area. Methods: The methodological basis is general scientific methods of cognition of legal phenomena, such as synthesis, the method of analogy, formal logic and others, as well as private scientific research methods. problems of framework agreements applied in the field of economic activity. Results and novelty: Conclusions are formulated on the essential conditions of the framework agreement and practical recommendations are provided for the conclusion of such agreements as regulators of economic and financial activities. The place of framework agreements in the implementation of certain types of economic and entrepreneurial activities, such as banking and insurance activities, is analysed.
\end{abstract}

\footnotetext{
*Corresponding author: fgslaw@mail.ru
} 


\section{Introduction}

Entrepreneurial and economic activity is developing in various directions [1]. The relevance of considering novels of contract law is due to the urgent need to comprehend innovations Civil Code of the Russian Federation (further - GK RF), prepared on the basis Concepts development of the civil legislation of the Russian Federation, which significantly change the direction and scope of legal regulation of economic relations arising in connection with the conclusion, execution and termination of civil contracts [2].

It should be noted that the practice of using framework contracts in organizational business legal relations is very diverse, and their application in each specific case is objective, as evidenced by D.O. Schniger point: "For example, for the owner of engineering infrastructure, a framework agreement for emergency repair is practically the only legal form of taking operational measures to prevent or eliminate the consequences of a disruption in the supply of utilities to consumers " [3]. It should be noted that a framework agreement is a legal structure that allows persons engaged in economic and entrepreneurial activities to fulfill a wish in any product, work, service of one party in exchange for receiving material benefits for this by the other party, while this need does not have the exact parameters at the time of the conclusion of such an agreement. At the same time, it is important that the main, basic, basic parameters of the interaction of subjects of economic relations can be agreed at once and at the same time they will have legal force throughout the entire period of interaction between the parties. Such an agreement allows you to calculate your budget for a significant period of time in the future, reduce costs, and is also the main component of the interaction of the parties - participants in financial and economic relations.

Framework contracts create economic relationships between the parties to entrepreneurial activity. At the same time, it is the framework agreement that creates the opportunity in the future to conclude the main agreement, or in any case, significantly simplifies its conclusion to ensure the stability of the economy and business.

\section{Results}

Undoubtedly, acts of will in the business community are important in economic legal relations, since a significant part of them arise and change in an initiative manner, i.e. at the will of a specific participant in a civil legal relationship [4]. The concept of a framework agreement in the field of economic activity is proposed - this is an agreement that defines the general conditions of obligatory economic relations of the parties, which can be specified and clarified by the parties by concluding separate property agreements (hereinafter referred to as the main agreement), including by filing applications of one of the parties in the manner an offer, and which is missing one or more of the essential conditions; of an economic nature, aimed at making a profit by one or both parties, concluded for the purpose of carrying out economic and business activities by one or both parties.

The essential conditions of the framework agreement used in economic activity have been determined. In addition to the subject of the framework agreement, these are: the term of the agreement, as well as such a characteristic of the subject of the main agreement as a key action of the party to the performance. An essential condition of a framework agreement in economic turnover is the fact of registration of one of the parties as a legal entity that has the right to engage in entrepreneurial and other economic activities or a citizen as an individual entrepreneur.

It seems impossible in order to ensure the economic obligation to conclude the main contract (consideration of the offer) in accordance with the framework contract in the field 
of economic activity, the application of a security deposit and withholding. It seems necessary in order to ensure the obligation to conclude the main contract (consideration of the offer) in accordance with the framework contract implemented in economic circulation, the application of a forfeit (fine), pledge, surety and an independent guarantee.

In business practice, framework business contracts, concretized by the filing of applications by one of the parties, are found in organizational business legal relations related to the provision of transport services (the contractor sends the customer an application for the supply of transport, which is an offer) and related to the supply of goods (the buyer under the framework supply agreement sends the supplier an application indicating the name and quantity of the required goods - an invitation to make an offer; based on the application, the supplier issues an invoice, which indicates, among other things, the delivery time of the goods, which the parties agreed to consider an essential condition (offer)) [3], incl. in the field of transportation of goods, baggage and passengers by various types of transport. "Most often, in the sphere of economic turnover, the question of what is meant by the organization of services related to the transportation of goods is difficult. At the same time, an equal sign is sometimes put between the organization of the carriage of goods and the organization of services related to the carriage "[5].

"One of the main trends in the development of both modern scientific knowledge in general and legal science in particular is the expansion of the use of a systematic approach in studying the nature of the phenomena under consideration. It is necessary to pay attention to the establishment of intersectoral links between civil, labor, family and business relations " [6]. Previously, judicial practice and economic relations completely denied the possibility of the existence of framework agreements, however, the sphere of economic activity, doing business gradually transformed until they were fully recognized as grounds for the emergence of obligations in the sphere of economics and finance.

\section{Discussion}

The specific purpose of framework agreements is to create a system of stable legal ties, common rules of the game, to which the relationship between the parties is subsequently subjected [7]. The legal definition of a framework agreement (agreement with open terms) is contained in clause 1 of Art. 429.1 of the Civil Code of the Russian Federation, where it is stated that a framework agreement (an agreement with open terms) is an agreement that defines the general conditions of the obligations of the parties, which can be specified and clarified by the parties by concluding separate agreements, filing applications by one of the parties or otherwise on the basis of either execution of the framework contract. This article also states that the relations of the parties that are not regulated by separate agreements, including in the event that the parties do not conclude separate agreements, are subject to the general conditions contained in the framework agreement, unless otherwise specified in individual agreements or follows from the essence of the obligation. It is advisable to call a framework agreement a contract,

"Economic activity, being a type of economic activity, includes the organization, provision, management and direct implementation of production " [8]. It should be admitted that "Until now, the family economy has not been seen as an alternative resource for the development of entrepreneurship in Russia. The transition to market relations has led to an increase in unemployment ... " [9]. One of the most significant examples of framework agreements in Russian and foreign law is their use when using derivative financial instruments (PFIs). It should be noted that in Russia derivatives began to be used even before the concept of a framework agreement was enshrined in the Civil Code of the Russian Federation. The lack of such anchorage was partly offset by the application of the 
rules of the International Swaps and Derivatives Association in our country. Since Russia is its member, Russian Master agreements are part of this system [10].

For the agreement to be recognized as concluded, the agreement of the parties in the field of economic activity must contain all the constitutive elements required by the norms of the law [11]. The main positive aspects of framework agreements are: 1) adaptability and dynamism for business partners; 2) clarity; 3) reducing the economic costs of negotiating terms and managing contracts; 4) their focus on long-term economic cooperation of the parties. These advantages are fully reflected in the application of framework agreements in business law and economic turnover, since it is in business that it is most necessary to be able to long-term planning of relationships between its participants.

The use of the mechanism for concluding, changing and terminating a framework agreement, as a rule, allows you to secure the creditor, who always wants to be sure that the debtor will fully and timely fulfill the obligations assumed [12]. As A.Yu. Burkova: "The parties, working with each other for a long time, begin to trust each other more, which not only positively affects their relationship under a specific framework agreement, but can also lead to new projects, for example, to investments in the development of a new product, etc. . "[13]. However, the most serious disadvantage of such agreements is the complexity of making changes to them, especially when their execution has already begun, separate agreements have been adopted or conditions have been clarified, etc.

L.G. Efimova reasonably determines the subject of framework agreements to cooperation in a certain field of activity [14]. Indeed, since the very construction of the framework contract presupposes to some extent the uncertainty of its terms, incl. subject (since the Civil Code of the Russian Federation does not fully specify the subject of the framework agreement), here it is possible to recommend using the principle of rationality (Article 10 of the Civil Code of the Russian Federation).

A framework agreement as an economic and legal category, concluded for the purpose of carrying out entrepreneurial activity, is a structural component of the legal composition, since a set of legal facts is required for the occurrence of certain legal consequences.

It is also necessary to point out that there is no need to introduce any framework and restrictions on the subject composition of framework contracts. It is logical that any business entity in carrying out entrepreneurial activities should have the opportunity to conclude such contracts, with the exception of certain types of framework contracts, the subjects of which can only be legal entities and individual entrepreneurs licensed to carry out a certain type of activity (for example, a party of decisive execution in agreements on the issuance of a credit line, agreements in the field of communications, medicine, and so on).

As E. B. Poduzova rightly recommends, in order to avoid ambiguity in possible litigation, it is best for the parties to directly indicate the obligation of the decisive performance to conclude the main contract or consider an offer from an interested party, since a different way of formulating further relations between the parties can lead to the disappearance of the legal dependence of the parties from each other and the loss of the framework agreement of its main feature that distinguishes it from other types of agreements [15].

Proceeding from the fact that the framework agreement is just a contract, from the moment of its conclusion, all provisions related to the protection of personal data, a clause of jurisdiction, an arbitration clause, provisions on confidentiality, on guarantees, and assurances fully apply to it. As for its significance as a document, the Civil Code of the Russian Federation speaks of the application of the provisions of the framework agreement to the relations of the parties not regulated by separate agreements, unless otherwise indicated in the main agreements, and does not contradict the essence of the obligation. This provision clearly indicates the unity of the legal structure of the framework and the 
main agreements. At the same time, it should be noted that in civil law relations, framework agreements are less in demand than in economic and business practice, since they rarely require long-term regulation of the relationship between the parties.

At the international legal level, there is a regulation of civil relations, entrepreneurial activity, relations with the participation of public institutions, state bodies. Relations in the field of protection and protection of property rights of the Russian Federation have the widest application at the international level, especially in the light of the so-called sanctions of foreign states currently applied to the Russian Federation, which are predominantly discriminatory towards Russia [16].

Consider the application of the institution of framework contracts in the regulation of financial relations. Such a type of framework agreements as a general (framework) agreement on the opening of a credit line has become quite widespread in the financial sector and banking practice - this is a framework agreement containing the conditions and procedure for opening a framework credit line by a credit institution to a borrower, including: 1) the obligation of a credit organizations to conclude with the borrower during the period specified in such an agreement at his request, the main loan agreement on the provision of funds to the borrower; 2) the maximum amount of the amount,

Art. 51.3 Federal Law "On the Securities Market" dated April 22, 1996 No. 39-FZ provides for the possibility of concluding a general agreement regulating the procedure for concluding and some conditions of repo agreements in cases where there is an intention of the parties to conclude more than one repo agreement. Such agreements may provide for: 1) the conditions and procedure for payment of funds and (or) transfer of securities in the event of a change in the price of securities or in other cases, while the amount of funds to be paid and (or) the number of securities to be transferred may be determined separately for each repo agreement, for a group of repo agreements and (or) for all repo agreements; 2) the grounds and procedure for the termination of obligations under the agreement (repo agreements) [15].

Art. 51.4 of the Law on the Securities Market provides for the possibility of concluding a general agreement governing the procedure for concluding and certain conditions of contracts that are financial derivatives in cases where there is an intention of the parties to conclude more than one contract that is a derivative financial instrument. Such agreements may provide for the grounds and procedure for the termination of obligations under all contracts concluded between the parties under the terms of the general agreement. [15]. The aforementioned repurchase agreements and agreements that are derivative financial instruments may be governed by the corresponding master agreements if they contain a clause indicating this. Art. 51.5 of the Law on the Securities Market provides for the possibility of concluding a general agreement under agreements, the object of which is securities and (or) foreign currency, governing the terms of concluding repo agreements and (or) agreements that are derivative financial instruments and (or) agreements of a different type, the object of which is securities and (or) foreign currency. There is also a practice of concluding general agreements on settlement forward transactions, which establish the content of transactions, the procedure for their conclusion and execution.

\section{Conclusion}

In different economic and legal systems, there are two approaches: in one case, the framework agreement is legally binding on the conclusion of the main agreement or consideration of the application for the conclusion of such; in the second, this agreement does not lead to the emergence of any rights and obligations for its parties until the main agreement is concluded. The institution of framework agreements is enshrined in the most 
general form and in international legal norms in force in Russia since the period when the framework agreement was not named in the Civil Code of the Russian Federation.

The framework agreement must contain conditions that allow establishing the main obligation of the party to the decisive performance under the main agreement (including the offer agreement), as well as an indication that there is no need to fulfill this obligation to supply goods with limited economic circulation, to perform licensed work, the provision of services, or a specific type of such goods, works, services, as indicated in the relevant regulatory legal acts and an indication of the availability of appropriate permits (licenses) from the party to the decisive execution or an obligation to obtain them. framework agreements concluded for the purpose of the parties (or one of the parties) conducting business activities additionally, in comparison with other framework agreements, the following features: 1) are always property in nature; 2) at the same time, the framework agreements themselves, both in entrepreneurial activity and outside it, do not contain a property obligation, but framework agreements in entrepreneurial activity oblige to conclude a basic agreement entailing specific obligations of a property nature; 3) are always aimed at potential profit, at least one of the parties, which follows from the legal definition of entrepreneurial activity, given in paragraph 1 of Art. 2 of the Civil Code of the Russian Federation, which states that entrepreneurial activity has the following characteristics: independence; implementation at your own risk; focus on regular profit from the use of property, sale of goods, performance of work or provision of services. but framework contracts in entrepreneurial activity oblige to conclude a basic contract, entailing specific obligations of a property nature; 3 ) are always aimed at potential profit, at least one of the parties, which follows from the legal definition of entrepreneurial activity, given in paragraph 1 of Art. 2 of the Civil Code of the Russian Federation, which states that entrepreneurial activity has the following characteristics: independence; implementation at your own risk; focus on regular profit from the use of property, sale of goods, performance of work or provision of services. but framework contracts in entrepreneurial activity oblige to conclude a basic contract, entailing specific obligations of a property nature; 3) are always aimed at potential profit, at least one of the parties, which follows from the legal definition of entrepreneurial activity, given in paragraph 1 of Art. 2 of the Civil Code of the Russian Federation, which states that entrepreneurial activity has the following characteristics: independence; implementation at your own risk; focus on regular profit from the use of property, sale of goods, performance of work or provision of services. one of the parties, which follows from the legal definition of entrepreneurial activity, given in paragraph 1 of Art. 2 of the Civil Code of the Russian Federation, which states that entrepreneurial activity has the following characteristics: independence; implementation at your own risk; focus on regular profit from the use of property, sale of goods, performance of work or provision of services. one of the parties, which follows from the legal definition of entrepreneurial activity, given in paragraph 1 of Art. 2 of the Civil Code of the Russian Federation, which states that entrepreneurial activity has the following characteristics: independence; implementation at your own risk; focus on regular profit from the use of property, sale of goods, performance of work or provision of services.

Since the norms of Art. 51.3 - 51.5 of the Law on the Securities Market speak only of the intention of the parties, then the above general agreements are framework agreements only if they contain an obligation for one of the parties to conclude, at the request of the other party, the main agreement (repo agreement; an agreement that is a derivative financial instrument ; Forward Settlement Agreement) or an obligation for both parties to enter into a host agreement. A framework agreement, including one concluded for the purpose of carrying out entrepreneurial activities by one or more of its parties, may be terminated on general or special grounds, liability for non-performance or improper performance may be of both property and non-property nature. Certain types of framework contracts, the most 
widespread in the business environment and economic activity, are: general policy; general (framework) agreement on the opening of a credit line; general agreements provided for by the Federal Law on the Securities Market; contract for the auction.

\section{References}

1 K.K. Dzhindzholiya, Law and Economics. 9, 49 - 55. (2020)

2 M.N. Ilyushina, Justice. 4, 5 - 10. (2017)

3 D.O. Shniger. Journal of Russian Law. 4, 12, 69-78. (2016) DOI: 10.12737/22721

4 M.N. Ilyushina, Laws of Russia: experience, analysis, practice. 12, 3 - 8. (2017)

5 S.Yu. Morozov, Civil law. 6, 3 - 7. (2017)

6 A.N. Levushkin, Civil law. 2, 7. (2019)

7 T.S. Gudovskikh, Current problems of Russian law. 8, 94 - 99. (2018)

8 I.V. Ershova, Lex russica, 9, 48. (2016)

9 A.N. Levushkin, P.A. Matveev, I.A. Tolstova, G.Y. Mitsyk, N.L. Avilova, International Journal of Recent Technology and Engineering. 8 Issue-4. 6085-6088. (2019)

10 S.A. Khabarov, Lawyer, 6, 4-8. (2015)

11 M.N. Ilyushina, Laws of Russia: experience, analysis, practice. 8, 3 - 9. (2019)

12 A.N. Levushkin, I.V. Zaikina, M.A. Bulavina, G.A. Kozlitin, V.V. Zaikin, PalArch's J. Archaeol. Egypt/Egyptol. 17(6), 6964-6973 (2020)

13 A.Yu. Burkova, Bulletin of Arbitration Practice, 6 (61), 58-62. (2015)

14 L.G. Efimova, Framework (organizational) contracts. P. 18. (Walters Kluver, Moscow, 2006).

15 E. V. Poduzova, Organizational agreements in civil law: monograph. (Prospekt, Moscow, 2015).

16 A.A. Vlasov, A.N. Levushkin, T.E. Rakhmatullin, L.E. Rakhmatullina, Journal: “Opcion”. 19, 721-736 (2019) 